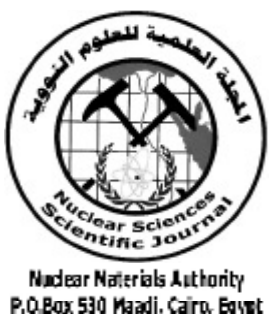

ISSN 2314-5609

Nuclear Sciences Scientific Journal

6, $123-135$

2017

http://www.ssnma.com

\title{
PETROGRAPHICAL, GEOCHEMICAL AND RADIOACTIVITY STUDIES ON GRANITE AND GRANODIORITE ASSOCIATIONS IN ASWAN CATARACTS, EGYPT
}

\author{
MOHAMED ABDEL MONSIF \\ Nuclear Materials Authority, Cairo, Egypt
}

\begin{abstract}
Aswan granites are divided into two types: 1) granite extends from Aswan north to El Shellal south and 2) granodiorite-quartz monzodiorite form two separated elongated and parallel bodies extending in N-S direction. At the contact between the two types there are some enclaves and ferromagnesian minerals.

Aswan granite is composed mainly of alkali-feldspars, plagioclase, quartz, biotite, hornblende. Allanite, zircon, monazite, fluorite, apatite, titanite and opaques are the main accessory minerals. Secondary minerals are muscovite, chlorite and carbonates. Two generations of quartz which included in hornblende, microclinization of plagioclase, presence of skeletal apatite, presence of secondary titanite in granite due to the presence of high titanium content which derived from granodiorite-quartz monzodiorite, the presence of zircon included in biotite and both of them mantled with hornblende and the presence of different types of textures, all the previous are some criterias for magma mixing.

There are some criteria in the geochemistry of the trace elements for magma mixing, presence of low content of $\mathrm{Ba}$ and $\mathrm{Sr}$ in granite as compared with granodiorite-quartz monzodiorite, low $\mathrm{Zr}$ content in granite but high in granodiorite-quartz monzodiorite, presence of high $\mathrm{Zn}$ and $\mathrm{Pb}$ in granite and the presence of small gab between the two rock samples which may be attributed to absence of complete spectrum of samples to causes such gabs.

This study revealed that the uranium content in granite is lower than that of granodiorite-quartz monzodiorite and the thorium content in granite is greater than that of granodiorite-quartz monzodiorite which give an indication for the mixing magma. On the other hand, the uranium content in both types are suitable for using this granite as ornamental stones.
\end{abstract}

\section{INTRODUCTION}

Aswan granites crop out between long. $32^{\circ} 50^{\prime}-32^{\circ} 55^{\prime} \mathrm{N}$ and lat. $24^{\circ} 00^{\prime}-24^{\circ} 05^{\prime}$ E (Fig.1).

Aswan granite is categorized with the Egyptian younger granites (YG) of (565592Ma) Abdel Monem \& Hurley (1980) and Hashad et al. (1972). This rock intrudes older rocks including schists and granite gneisses.
It forms the base of the modern Aswan town foundation and the surrounding urban including some islands in the River Nile and the Old Aswan Cataracts. At the south and west of Aswan city, the suite is covered by Nubian Sandstone. The oldest open quarry in the world is still preserved in this granite where uncompleted obelisk is excavated into the rock and left there because it met with fracture (Gindy\&Tamish,1998). 


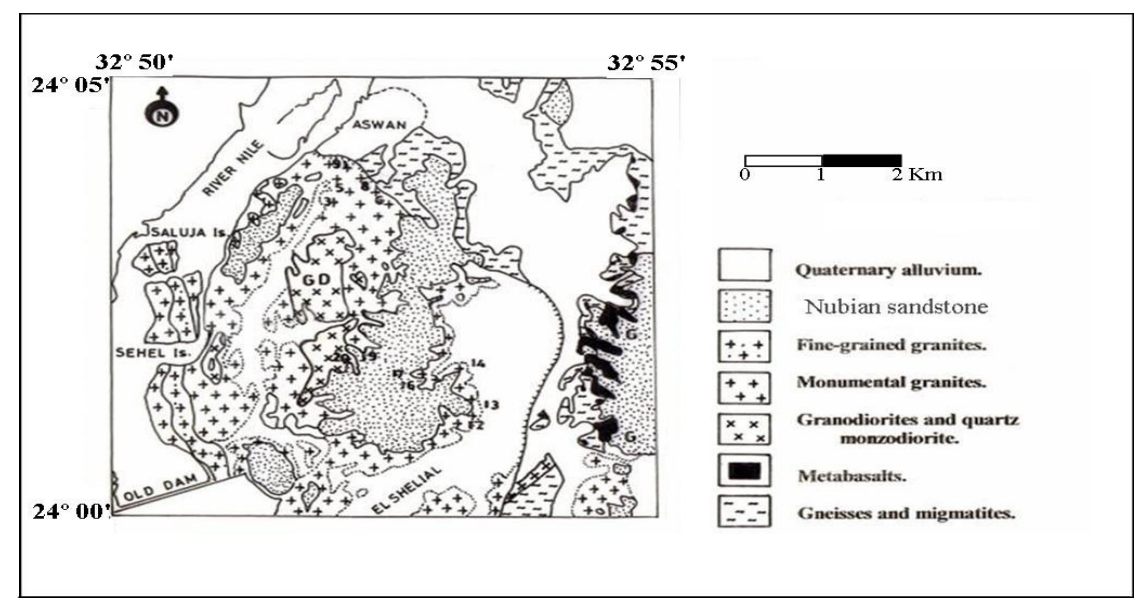

Fig.1:Geologic map of Aswan monumental granitoid suite (Modified after Gindy \& Tamish, 1998)

Many authors studied this granite because of its unique textural, compositional and origin with respect to that settled for the younger granite (YG). For example, Barthoux (1922), Andrew (1934), Hume (1935) and Gindy (1974) considered a magmatic intrusive origin for this granite. On the other hand, El-Shazly (1954) observed an uncommon porphyroblastic rocks highly injected with pegmatite with no distinct foliation within the metamorphic rocks around the Aswan granite. This led him to postulate that the addition of alkalis and silica to the preexisting metamorphic rocks could produce granodiorites and the coarse-grained granite of the Aswan granites.

Gindy (1954, 1956 and 1957), Higazy \& Wasfy (1956) and Zaghloul \& Khaffagy (1965) considered a metasomatic origin of these granites according to their studies on separated zircon crystals. Abu-El-Ela (1973) compared the morphology of zircon crystals separated from the metamorphic country rocks with those from the Aswan granitoids as described in Zaghloul \& Khaffagy (1965) and he realized that the Roundness Index of the country rocks zircons ( $73 \%-98 \%)$ is much greater than that of coarse-grained granites
(42\%-50\%).

Taher (1976) analyzed the biotite separated from the Aswan Granites and supported the magmatic origin claimed previously by Gindy (1974). He concluded that the Aswan Granites form a post-orogenic composite stock. It constitutes of granodiorites, coarsegrained granites, fine-grained granites and leucogranites having intrusive nature and co-magmatic origin.

Gindy and Tamish (1998) concluded that due to the collisional suture that extend at $\mathrm{N}$ $\mathrm{S}$ and meridian to the present Nile at Aswan and continued southwards into the Sudan and Ethiopia, the collisional thickening, partial melting occurred in the lower crust and upper mantle and both melts mixed together and eventually produced earlier granodioritic magma and a later monzogranitic magma that had arisen to form the post-collisional post-kinematic granitoids of the area.

El Tokhi and Saleh (2001) stated that the evolution of pan african Aswan-type rapakivi granite, southeastern of Aswan city. Texturally, tree types of rapakivi granites were identified, South Eastern wiborgite, pyterlite and porphyritic. Petochemical parameters 
and variation diagrams suggest that these rapakivi granites were formed by parial melting of silica crustal rocks mixed with mafic material.

Ammar (2003) stated that the monumental granitic rocks at Aswan cataract comprise a suite of rocks having metaluminous, calc alkaline affinities, represented by granite and granodiorite-quartz monzodiorite. At the contact between these types abundance of rounded to elongated microgranitoid enclave and their textural assemblage (e.g. interstitial, resorbed rims, chemical zoning and rapakivi) are interpreted as mixing having occurred between two penecontemporaneously emplaced magmas.

This paper deals with the geology, petrography and uranium, some trace elements geochemical features at Aswan granites. Also, the aim of this study declares the evidences of magma mixing and the uranium content which may be affect on the water or the granite which used as ornamental stones. Eighteen samples (eleven from granite and seven from granodiorite-quartz monzodiorite) were collected each sample more than $10 \mathrm{~kg}$ for petrographic and geochemical studies.

\section{GEOLOGIC SETTING}

Generally, the Aswan granites are intruded into country rocks composed of biotite granitic gneisses and schists of Proterozoic age (Abdel Monem \& Hurley, 1980). The contacts are usually sharp intrusive one. These rocks are covered by Nubian Sandstone (N.S.S).

\section{Biotite Gneisses and Migmatites}

The biotite gneisses and migmatites are the oldest rocks in the area. They are fine- to coarse-grained rocks, varying in color from brownish grey to dark grey. Sometimes, the rock shows light color due to the increase of feldspar minerals and decrease in biotite percent. They are mostly described at the eastern contacts of the Aswan granites.

\section{Aswan Monumental Granites}

The Aswan granites are coarse-to very coarse-grained rock unit. It composed of two rock varieties granite and granodioritequartz monzodiorite rocks (Ammar, 2003). The granite is extending from Aswan north to El Shellal south and underlying the N.S forming many conspicuous hills. The granodiorite-quartz monzodiorite rocks form two separated elongated and parallel bodies extending in N-S direction. The eastern body is larger than the western one. The contacts between these rock types are mostly crenulated and dipping about $40^{\circ}$ in the NNE direction (Fig.2). At the contact enclaves (Fig.3) and ferromagnesian minerals (Fig.4) increase in the granite towards the peripheries with granodiorite-quartz monzodiorite bodies. Quartz and feldspar phenocrystals increase in the granodiorite-quartz monzodiorite rocks towards the margins with granites. Four main rock varieties are defined as a member of the studied suite (Ammar, 2003) :

1-Aswan granite containing abundant large , rounded and elongated enclaves.

2-Granitic rock enrichment by mafic minerals and containing abundant enclaves of small scale.

3-Granodioritic rocks containing alkali feldspar and quartz phenocrystals.

4-Quartz monzodioritic rocks.

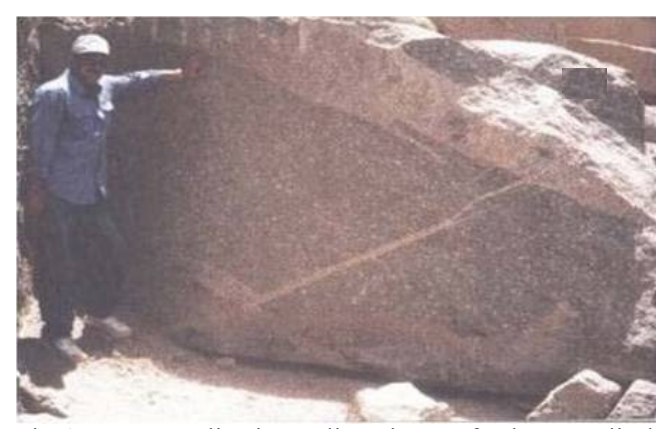

Fig.2: NNE dipping direction of the studied granites 


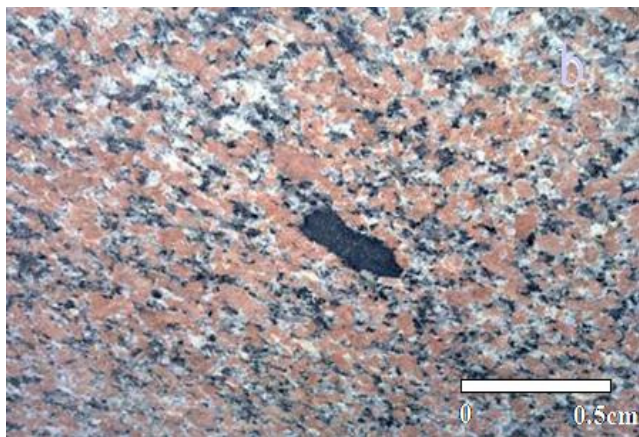

Fig.3: Elongated enclave in the studied granites.

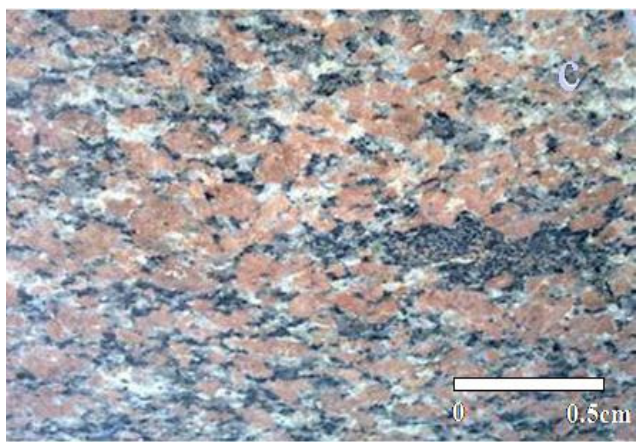

Fig.4: Ferromagnesian minerals distributed in the studied granites

The contacts between these rock members indicate the contemporaneous emplacement of both granitic and granodioritic-quartz monzodioritic magmas.

Mafic enclaves in Aswan granite are generally regular in the form of elliptical shape, fine-grained and distributed in all the granite body. They range in diameter from few centimeter up to one meter and feldspar crystals in the enclaves are oriented in alignment parallel to the feldspar crystal of the host granitic rocks indicating that the earliest phase remained in a magmatic state until other phase had been emplaced (Ammar,2003). These enclaves are widespread in most collisional granitoid (Reid et al., 1983; Vernon, 1984; Frost \& Mahood, 1987; Vernon et al.,
1988; Poli et al., 1989).

The measured linear orientation of feldspar and ferromagnesian minerals at the central part of the Aswan granite body plunges between $15^{\circ}$ to $64^{\circ}$ in the NW and SW directions (Ammar,2003). Some later phases of aplitic and Tertiary mafic dikes were recorded cutting this granites.

\section{PETROGRAPHY}

Aswan granites are composed mainly of alkali-feldspars, plagioclase, quartz, biotite, hornblende. Allanite, zircon, monazite, fluorite, apatite, titanite and opaques are the main accessory minerals, while the secondary minerals are muscovite, chlorite and carbonates .

Alkali-feldspars: They are coarse to very coarse grains represented by perthite which include patchy perthite (Fig.5) and string perthite. Microcline is assocciated with perthite (Fig.6), microcline perthite (Fig.7).

Plagioclase: It is coarse to very coarse grains which digested by perthite (Fig.8). Plagioclase is also found mantled by perthite (Figs. $9 \& 10$ ) refering to the mixing magma. On the other hand, plagioclase may be transformed to microcline (Fig.11).

Quartz: It is coarse grains found in two generations, primary and secondary quartz in-

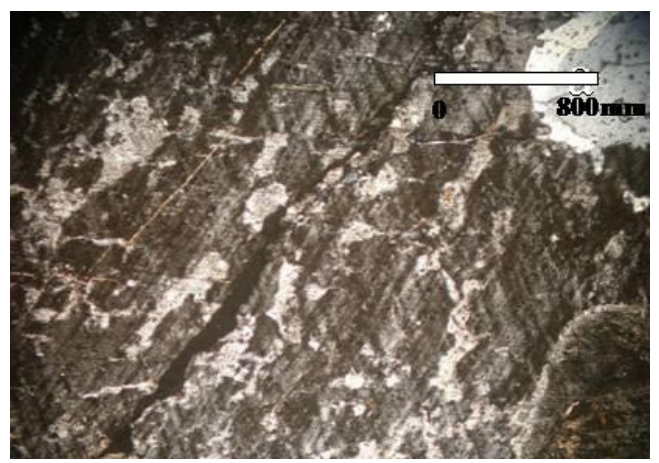

Fig.5: Photomicrograph showing patchy perthite in Aswan granite, XPL 


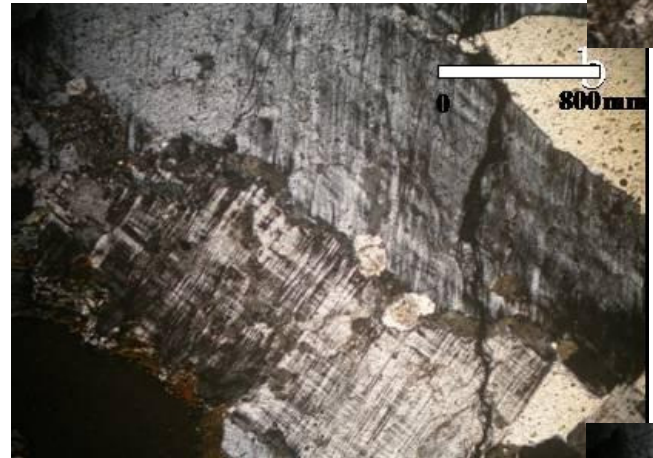

Fig.6: Photomicrograph showing microcline asssocciated with perthite in Aswan granite, XPL

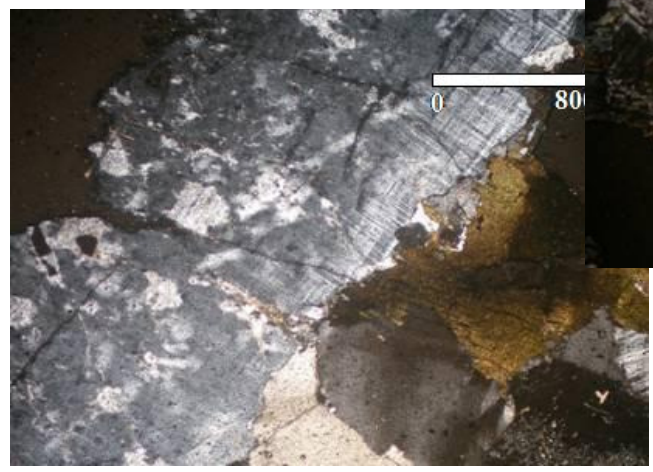

Fig.7: Photomicrograph showing microcline perthite in Aswan granite, XPL

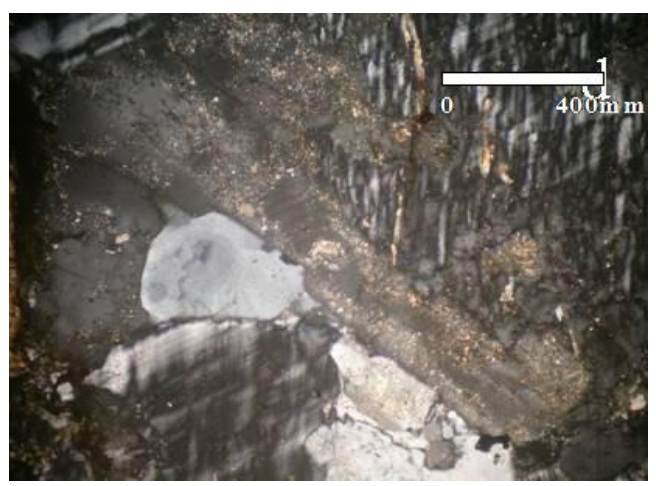

Fig.8 : Photomicrograph showing plagioclase digested by perthite in Aswan granite, XPL

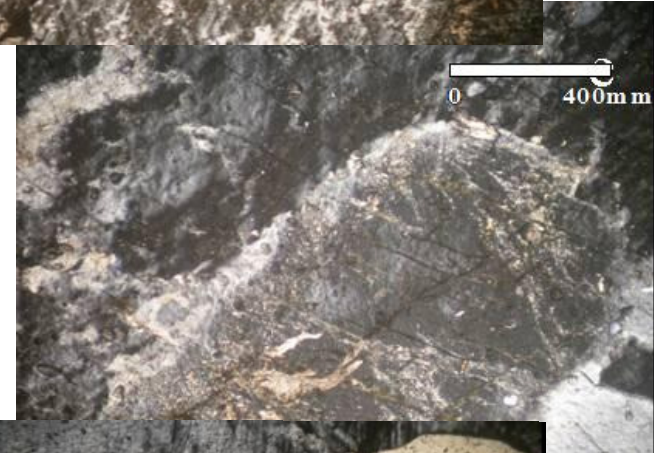

Fig.9 : Photomicrograph showing plagioclase mantled by perthite in Aswan granite, XPL

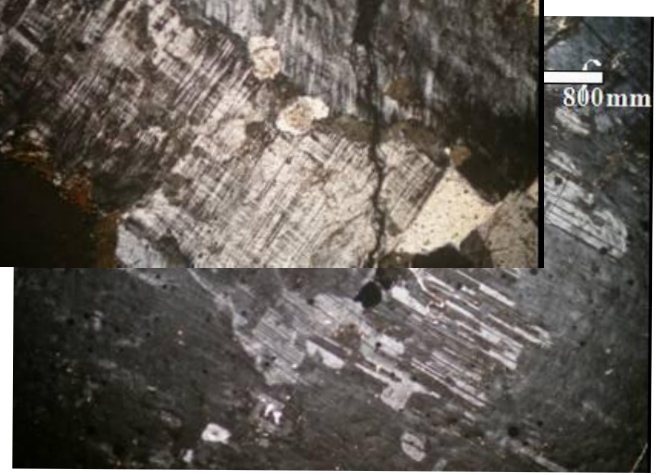

Fig.10: Photomicrograph showing plagioclase mantled by perthite in Aswan granite, XPL

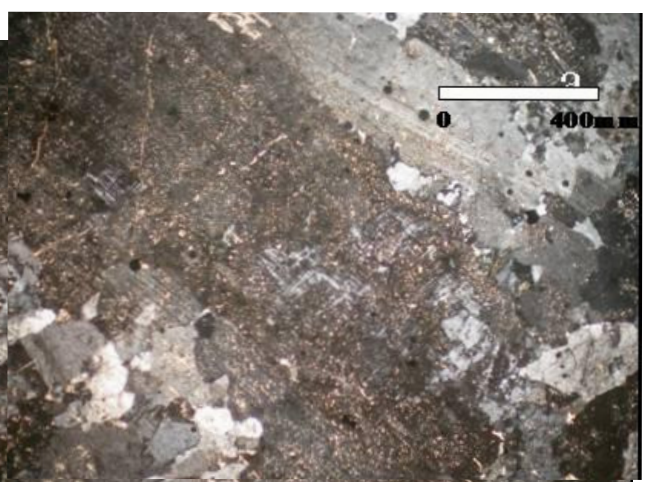

Fig. 11: Photomicrograph showing microclinization of plagioclase in Aswan granite, XPL 
cluding in hornblede crystal (Fig. 12). The two generations of quartz in hornblende refer to the presence of two magma mixing.

Biotite: It is medium to coarse grains carrying apatite crystal (Fig.13) and may be altered to chlorite.

Hornblende: It is medium to coarse grains found hosting two generations of quartz. On the other hand, zircon included in biotite (present the original phase of granite) and both of them are mantled with hornblende (Fig. 14). These arrangement is the reverse with Bowen reaction series which give

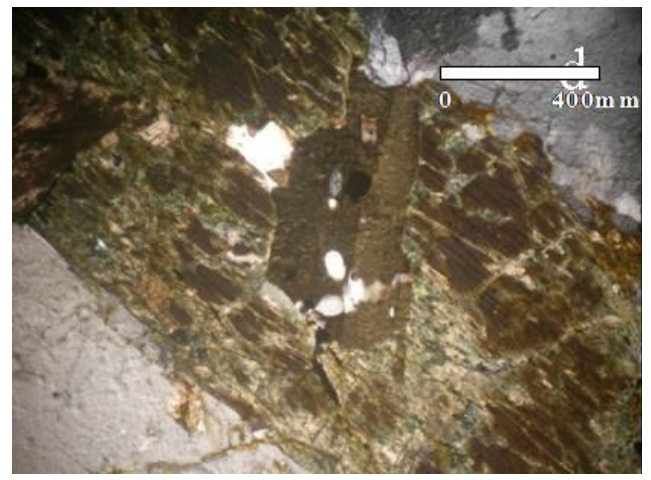

Fig.14: Photomicrograph showing zircon included in biotite and all mantled by hornblende in Aswan granite, XPL

a good evidence for magma mixing.

Apatite: It is found as skeletal crystal of apatite (Fig.15).

Titanite: It is found as secondary sphene due to the presence of high titanium content and assocciated with chlorite (Fig.16).

In Aswan granite there are several types of textures represented by rapakivi (Fig.17), non rapakivi, perthitic and granitic textures, also myrmekitic texture is found (Fig.18).

Rapakivi texture is used to describe plasecondary quartz included in hornblende in Aswan granite, XPL

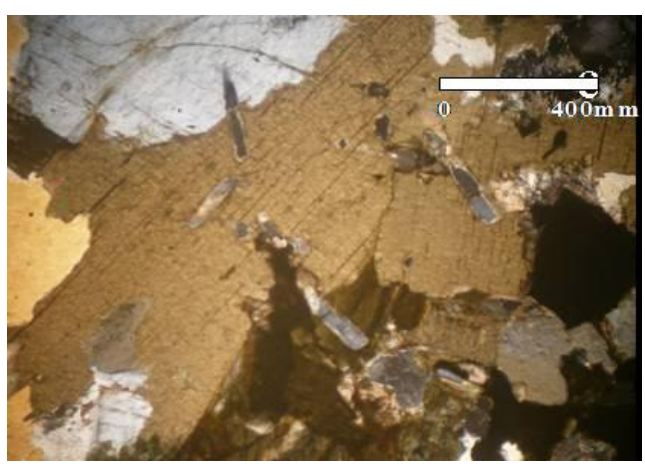

Fig.13: Photomicrograph showing apatite included in biotite in Aswan granite, XPL

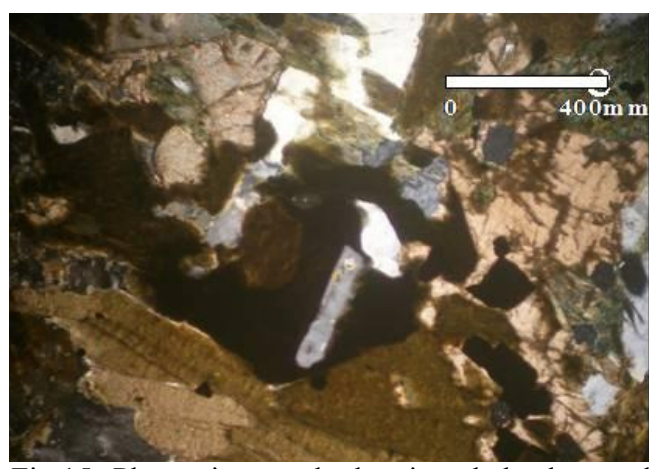

Fig.15: Photomicrograph showing skeletal crystal of apatite in Aswan granite., XPL 


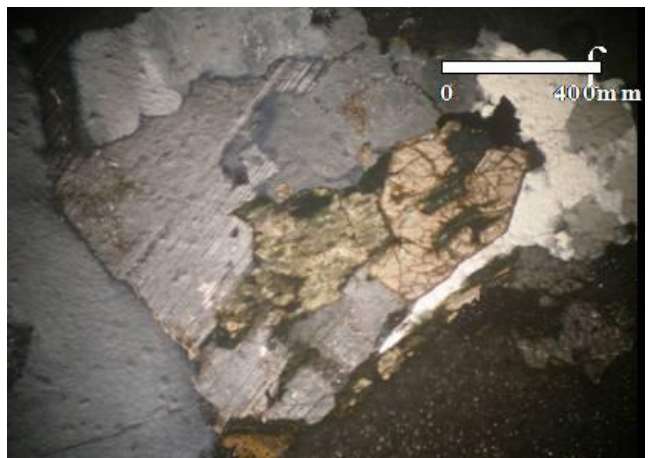

Fig.16: Photomicrograph showing titanite crystal associated with chlorite in Aswan granite, XPL

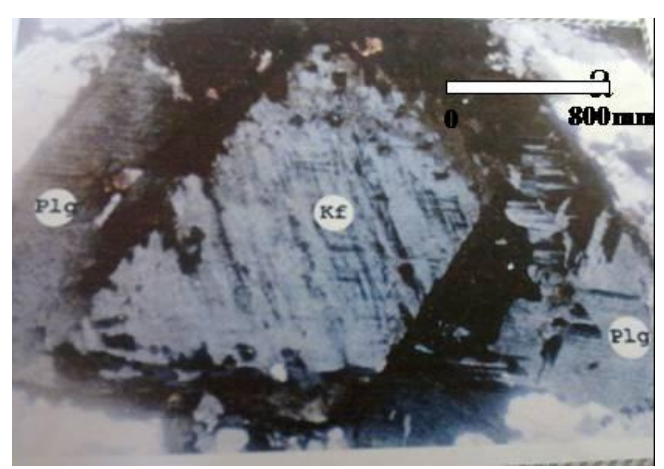

Fig.17: Photomicrograph showing rapakivi-like texture; K-feldspar is mantled by plagioclase in Aswan granite, XPL

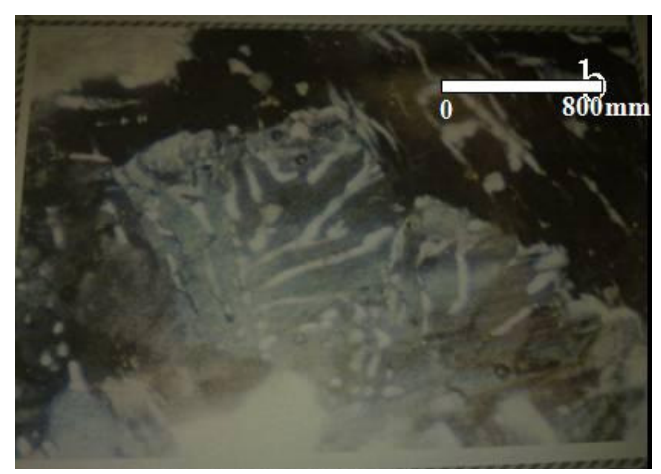

Fig.18: Photomicrograph showing myrmekitic texture in Aswan granite, XPL gioclase-mantled alkali feldspar phenocrysts. Wahl,1925; Savolahti, 1962 and Vorma,1971 conclude that the rapakivi texture mechanisms include : a) degassing of fluid-saturated magma, b) decompression, c) magma mixing.

Myrmekitic texture is found in porphyritic granite and formed due to the action of metasomatic processes with the exsolution around the margins of feldspars phenocrysts (Ashworth, 1979).

Granodiorite and quartz monzodiorite rocks are composed mainly of plagioclase, microcline, quartz, biotite and hornblende. The main accessory minerals are titanite, zircon, apatite and opaques. Some samples show antiperthitic texture.

Generally, the petrographic studies show that there are several evidences for magma mixing in Aswan granite:-

1-Presence of different types of textures (Hibbard, 1991).

2-Two generations of quartz which included in hornblende.

3-Microclinization of plagioclase.

4-Presence of skeletal apatite .

5-Presence of secondary titanite in granite due to the presence of high titanium content which derived from granodiorite -quartz monzodiorite.

6-The presence of zircon included in biotite and both of them mantled with hornblende.

\section{GEOCHEMISTRY}

Eighteen samples (eleven from granite and seven from granodiorite-quartz monzodiorite) were analyzed for trace elements, uranium and thorium in the laboratory of Henri Poincare University, Nancy, France (Table1). These elements were analyzed by Atomic Emission Spectrometer (AES) coupled with Inductively Plasma (IP) source.

The trace elements in granitic rocks are 
Table 1:Trace elements,uranium and thorium geochemistry of Aswan granites,South Eastern Desert,Egypt

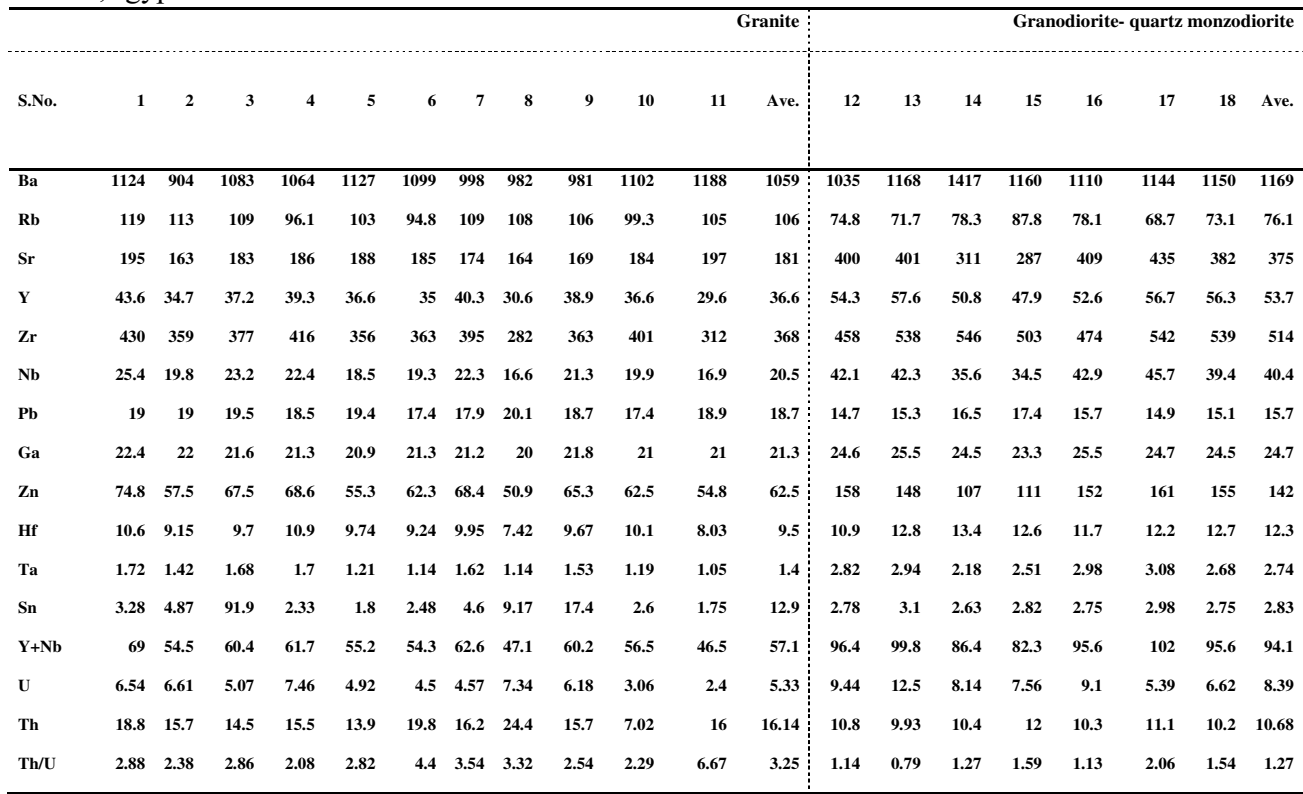

classified into metallogenic elements, that tend to be associated with the processes of mineralization as $\mathrm{Sn}, \mathrm{W}, \mathrm{Mo}, \mathrm{Cu}, \mathrm{Li}, \mathrm{Be}$, $\mathrm{Pb}, \mathrm{Zn}, \mathrm{Au}, \mathrm{U}, \mathrm{Ag}, \mathrm{F}$ and $\mathrm{Cl}$ and petrogenic elements associated with the normal magmatic processes of granitic melts as $\mathrm{Rb}, \mathrm{Ba}$, $\mathrm{Sr}, \mathrm{Y}, \mathrm{Zr}, \mathrm{Nb}, \mathrm{Ta}, \mathrm{Pb}, \mathrm{Sc}, \mathrm{Ga}, \mathrm{REE}$, and Th. Some of the petrogenic elements as $\mathrm{Ba}$, $\mathrm{Nb}$, Ta, Th and REE may become highly enriched during mineralization processes and form mineral deposits.

It is noticed the following from Table (1):

Generally, granite has high contents of $\mathrm{Ba}$ and $\mathrm{Sr}$ as compared with the granodioritequartz monzodiorite, although the low contents of $\mathrm{Ba}$ and $\mathrm{Sr}$ in this granite may be due to the mixing of magma. On the other hand, $\mathrm{Ba}$ content is more higher than Sr content in this granite mostly due to the substitution of $\mathrm{Ca}$ with $\mathrm{Ba}$.

Generally, Zircon content in granite has high values rather than that of the granodiorite-quartz monzodiorite, but in the studied granite $\mathrm{Zr}$ content is lower than the granodiorite-quartz monzodiorite which reflect the mixing of magma.

Zinc content is low in granite and high in granodiorite-quartz monzodiorite, although, the $\mathrm{Zn}$ contents in studied granite and granodiorite-quartz monzodiorite are high being due to the mixing of two magmas.

Lead content in granodiorite-quartz monzodiorite is higher than granite, but in the studied granite $\mathrm{Pb}$ content is relatively higher than the granodiorite-quartz monzodiorite which also due to the evidence of magma mixing.

Uranium content in granite range from (2.4ppm to $7.46 \mathrm{ppm}$ ) with average 5.33 being lower than the content in granodiorite-quartz monzodiorite (5.39ppm to $12.5 \mathrm{ppm}$ ) with average 8.39 . Thorium content in granite range 
from $7.02 \mathrm{ppm}$ to $24.4 \mathrm{ppm}$ with average 16.14 which is greater than the content in granodiorite-quartz monzodiorite $(9.93 \mathrm{ppm}$ to $12 \mathrm{ppm}$ ) with average 10.68 . These values are opposite to the normal,so they also may give an evidenve for magma mixing.

From Table (2), the average of trace elements in the studied granite is not matching the average of the younger granites of El Gaby (1975) and low- Ca granites of Turekian and Wedepohl (1961). This may indicate that the studied granites had a different history than the standard or usual granite.

Figures (19-26) show some relationships between trace elements which show the increasing or decreasing and presence of straight-line or not between them.

From $\mathrm{Ba}-\mathrm{Sr}$ diagram, there is a direct relationship between $\mathrm{Ba}$ and $\mathrm{Sr}$ and straight-line in the granite. On the other hand, most samples of the granite have $\mathrm{Ba}$ and $\mathrm{Sr}$ content relatively equal to that of the granodiorite-quartz monzodiorite which give an indication for magma mixing (Fig.19).

From $\mathrm{Rb}-\mathrm{Sr}$ diagram, there is a reverse relation between $\mathrm{Rb}$ and $\mathrm{Sr}$ in both granite and granodiorite-quartz monzodiorite, but $\mathrm{Rb}$ content in granite is greater than that

Table 2: The average composition of trace elements of Aswan granites compared with the average of El Gaby (1975) and Turekian and Wedepohl (1961) granites

\begin{tabular}{lrrrr}
\hline & \multicolumn{5}{c}{ Study granite } & $\begin{array}{r}\text { El Gaby } \\
(1975)\end{array}$ & $\begin{array}{r}\text { Turekian and Wedepohl } \\
(1961)\end{array}$ \\
& granite & $\begin{array}{c}\text { granodiorite-quartz } \\
\text { monzodiorite }\end{array}$ & & \\
\hline $\mathrm{Ba}$ & 1059 & 1169 & 403 & 840 \\
$\mathrm{Rb}$ & 106 & 76.1 & 177 & 170 \\
$\mathrm{Sr}$ & 181 & 375 & 39.6 & 100 \\
$\mathrm{Y}$ & 36.6 & 53.7 & 41.4 & 40 \\
$\mathrm{Zr}$ & 368 & 514 & 293 & 175 \\
$\mathrm{Nb}$ & 20.5 & 40.4 & 15.7 & 21 \\
$\mathrm{~Pb}$ & 18.7 & 15.7 & - & 19 \\
$\mathrm{Ga}$ & 21.3 & 24.7 & - & 39 \\
$\mathrm{Zn}$ & 62.5 & 142 & - & \\
\hline
\end{tabular}

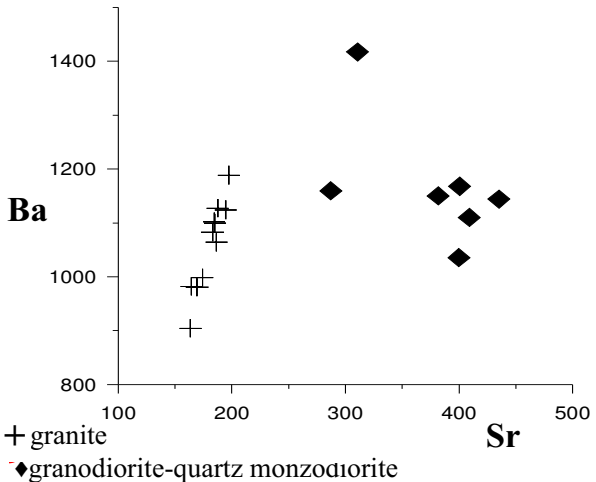

Fig.19: Ba versus Sr relationship in Aswan granite and granodiorite-quartz monzodiorite

of granodiorite-quartz monzodiorite as well as $\mathrm{Sr}$ content is greater in granodiorite-quartz monzodiorite than granite (Fig. 20).

$\mathrm{Nb}-\mathrm{Y}$ diagram shows a direct relationship with straight-line between $\mathrm{Nb}$ and $\mathrm{Y}$ in both types of rocks, but the contents of $\mathrm{Nb}$ and $\mathrm{Y}$ in granite is lower than the contents of granodiorite-quartz monzodiorite (Fig. 21).

$\mathrm{Rb}-(\mathrm{Y}+\mathrm{Nb})$ diagram declare a reverse relation between $\mathrm{Rb}$ and $(\mathrm{Y}+\mathrm{Nb})$ in both types. On the other hand, $\mathrm{Rb}$ content in granite is greater than granodiorite-quartz monzodiorite but the $(\mathrm{Y}+\mathrm{Nb})$ content in granite is lower than the other (Fig. 22).

$\mathrm{Hf}-\mathrm{Zr}$ diagram shows a direct relation between $\mathrm{Hf}$ and $\mathrm{Zr}$ in both granite and granodiorite-quartz monzodiorite with straight-line. On the other hand, $\mathrm{Hf}$ and $\mathrm{Zr}$ in granite is lower than the other. $\mathrm{Zr}$ in granite is lower than in granodiorite-quartz monzodiorite giving criteria for magma mixing (Fig. 23).

Th- $U$ diagram shows a direct relation in granite with no relation in granodiorite-quartz monzodiorite. The values of uranium in granite is lower than that in granodiorite-quartz monzodiorite but the values of thorium in granite is higher than that in granodioritequartz monzodiorite (Fig. 24). 
132

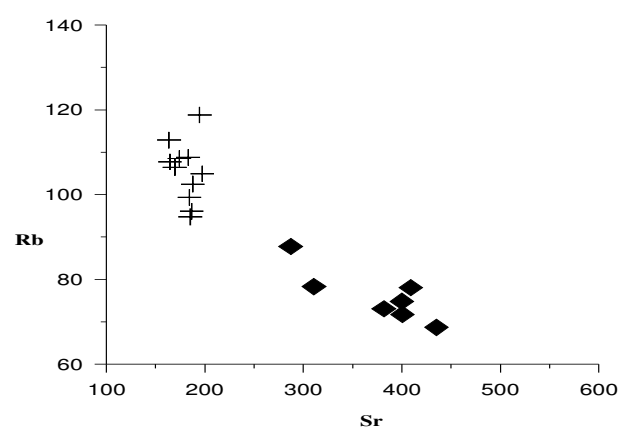

Fig.20: $\mathrm{Rb}$ versus $\mathrm{Sr}$ relationship in Aswan granite and granodiorite-quartz monzodiorite

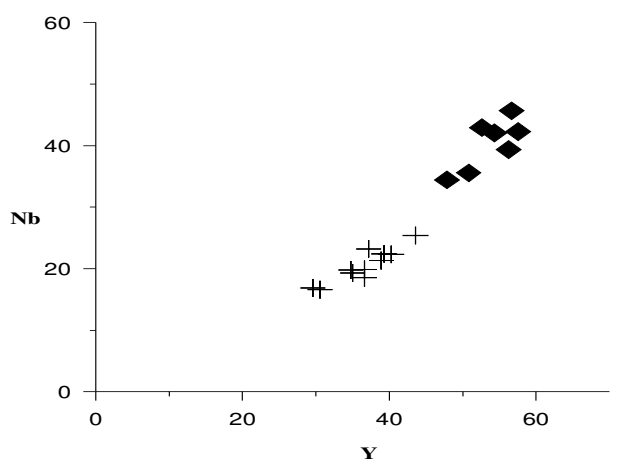

Fig.21: $\mathrm{Nb}$ versus Y relationship in Aswan granite and granodiorite-quartz monzodiorite

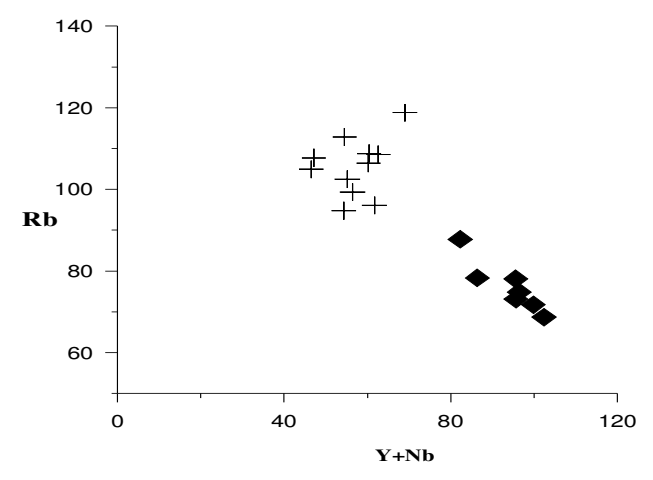

Fig.22: $\mathrm{Nb}$ versus $\mathrm{Y}+\mathrm{Nb}$ relationship in Aswan granite and granodiorite-quartz monzodiorite

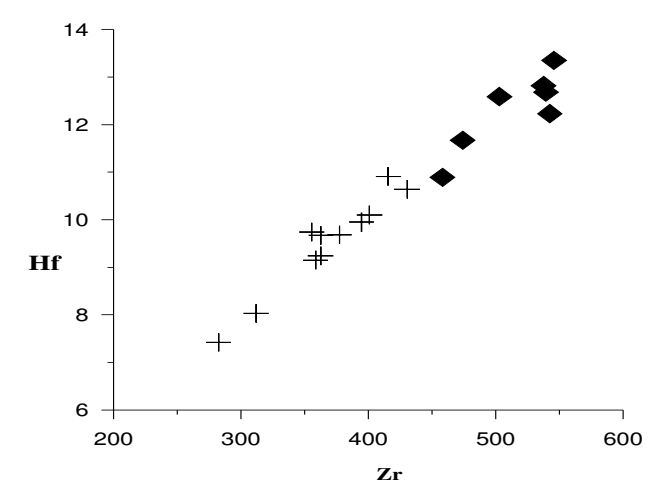

Fig.23: Hf versus $\mathrm{Zr}$ relationship in Aswan granite and granodiorite-quartz monzodiorite

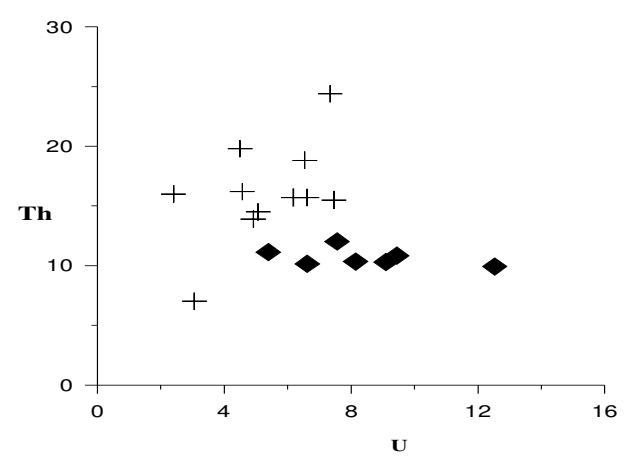

Fig.24: Th versus U relationship in Aswan granite and granodiorite-quartz monzodiorite

$(\mathrm{Th} / \mathrm{U})-\mathrm{Th}$ diagram shows that the increasing in (Th) content the $(\mathrm{Th} / \mathrm{U})$ ratio is also increasing in both type. On the other hand, $\mathrm{Th} / \mathrm{U}$ ratio in granite is greater than granodiorite-quartz monzodiorite ratio due to the enrichment of uranium in granodioritequartz monzodiorite than granite (Fig.25).

From (Th/U)-U diagram, it is declared that the two rock unites show a reverse relation between $U$ and $T h / U$ ratio but this relation is higher in granodiorite-quartz monzodiorite than granite due to the increasing of $U$ in granodiorite-quartz monzodiorite (Fig.26).

Generally, there are some criterias in the 


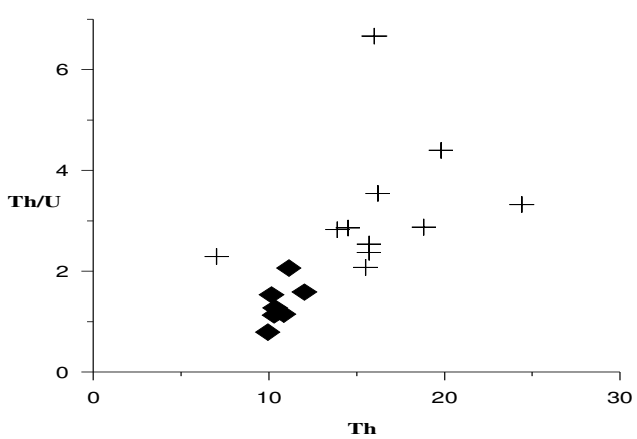

Fig.25: Th/U versus Th relationship in Aswan granite and granodiorite-quartz monzodiorite

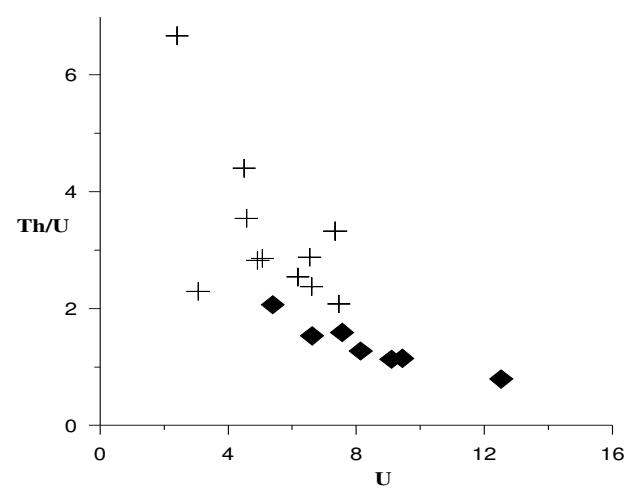

Fig.26: Th/U versus U relationship in Aswan granite and granodiorite-quartz monzodiorite

geochemistry of the trace elements for magma mixing, presence of high content of $\mathrm{Ba}$ and $\mathrm{Sr}$ in granite, low $\mathrm{Zr}$ content in granite but high in granodiorite-quartz monzodiorite, presence of high $\mathrm{Zn}$ and $\mathrm{Pb}$ in granites and the increasing of uranium in granodiorite-quartz monzodiorite than in granite is an evidenc for magma mixing.

\section{CONCLUSIONS}

Aswan granites are divided into two types, granite and granodiorite-quartz monzodiorite. Some enclaves and ferromagnesian minerals are noticed at the contact between the two types.
Criteria for magma mixing are noticed in petrographical studies such as presence of different types of textures, two generations of quartz which included in hornblende, microclinization of plagioclase, presence of skeletal apatite, presence of secondary titanite in granite due to the presence of high titanium content which derived from granodioritequartz monzodiorite and the presence of zircon included in biotite and both of them mantled with hornblende.

There are some criterias in the geochemistry of the trace elements for magma mixing, presence of low contents of $\mathrm{Ba}$ and $\mathrm{Sr}$ in granite as compared with granodiorite-quartz monzodiorite, low $\mathrm{Zr}$ content in granite but high in granodiorite-quartz monzodiorite, presence of high $\mathrm{Zn}$ and $\mathrm{Pb}$ in granite. The study revealed that, the uranium content in granite is lower than that of granodiorite- quartz monzodiorite and the thorium content in granite is greater than that of granodiorite- quartz monzodiorite which give an indication for the mixing magma. On the other hand, the uranium content in both types are suitable for using this granite as ornamental stones.

\section{REFERENCES}

Abdel Monem A.A., and Hurley, BP.M., 1980. Age of Aswan Monumental granite, Egypt by U$\mathrm{Pb}$ dating of zircons. Bull. Inst. Applied Geol., King Abdul Aziz Univ., Jeddah, 3(3), 141-144.

Abu-El-Ela, M.S., 1973. Study on the accessory minerals of the crystalline rocks of Aswan area and its petrologic significance. M. Sc., Ain Shams Univ.

Ammar, S.E., 2003. Acidic and intermediate rocks suite at Aswan Cataract; Petrogenetic studies. Egypt. J. Geol., 47/2, 1199-1213.

Andrew, G., 1934. Note on the "Cephren diorite". Bull. Inst. Egyptian, Cairo, XVI, 105-109.

Ashworth, J.R., 1979. Genesis of the Skagit Gneiss migmatites, Washington and the distinction between posssible mechanisms of migmatization: Discussion and reply. Geol. Soc. Am Bull., 90, 
887-888.

Barthoux, J.C., 1922. Chronologic et description des roches ignees du Desert arabique. Mem. Inst. Egypte, t. s., Le Cairo, 262p.

El-Gaby, S., 1975. Petrochemistry and geochemistry of some granites from Egypt. N. Jb. Mineral. Abh., 124-189.

El-Shazly, E.M., 1954. Rocks of Aswan area. Geol. Surv. Egypt. Mines and Quarries Dept. Cairo, $23 \mathrm{p}$.

El-Tokhi, M.M., and Saleh, G.M., 2001. The evolution of pan African Aswan-type rapakivi granite, Geochemical evidences from the South Eastern Desert of Egypt. Egypt. J. Geol., 45/1, 295-307.

Frost, T.P., and Mahood, G.A., 1987. Field, chemical and physical constraints on mafic-felsic magma interaction in the Lamarck Granodiorite, Sierra Nevada, California. Geol. Soc. Am. Bull., 99, 272-291.

Gindy, A.R., 1954. The plutonic history of the Aswan area, Egypt. Geol. Mag., 91, 484-497.

Gindy, A.R., 1956. The igneous and metamorphic rocks of the Aswan area, Egypt; Their description, origin and age relations. Bull. Inst. Egypte, tom, 37/2, 83-102.

Gindy, A.R., 1957. Certain geological observations and their important implications in the petrogenesis of rocks from the Aswan district, Egypt and some other related granitization geosynclines. $3^{\text {rd }}$ Arab. Sci., Cong., Beirut., 611-715.

Gindy, A.R., 1974. Geochemistry and petrogenesis of basement rocks in the environs of Aswan town. Abstract. Ann. Meeting, Geol. Soc. Egypt.

Gindy, A.R., and Tamish, M.M., 1998. Petrogenic revision of the basement rocks in the envirns of Aswan southern Egypt. Egypt. J. Geol. ,42/1, $1-14$

Hashad, A.H.; Sayyah, T.A.; El Kholy S.B., and Youssef, A., 1972. Rb-Sr isotope age determi- nation of some basement Egyptian granites. Egypt. J. Geol., 16, 169-181.

Hibbard, M.J., 1991. Textural anatomy of twelve magma-mixed granitoid systems: In Enclaves and Granite Petrology. Developments in petrology (Didier, J. and Barbarin, B., Eds.), Elsevier, Amsterdam, 13, 431-444.

Higazy, R.A., and Wasfy, H., 1956. Petrogenesis of granitic rocks in the neighbourhood of Aswan, Egypt. Bull. Inst. Desert, 6, 209-256.

Hume, W.F., 1935. Geology of Egypt. The later plutonic and minor intrusive rocks. Geol. Surv., Cairo, II/II, 301-688

Poli, G.; Ghezzo, C., and Conticelli, S., 1989. Geochemistry of granitic rocks from the Hercynian Sardinia-Corsica batholith: implication for magma genesis. Lithos, 23(4), 247-266.

Reid, J.B.; Evans, O.C., and Fates, D.G., 1983. Magma mixing in granitic rocks of the Central Sierra Nevada. California. Earth Planet. Sci. Lett., 66, 243-261.

Savolahati, A., 1962.The rapakivi problem and the rules of idiomorphism in minerals. Bull. Comm. Geol.Finlande ,204, 15-67.

Taher, R.M., 1976. Petrological studies on some granitic rocks of Aswan area, Egypt. M Sc. Thesis, Ain Shams Univ. Cairo, Egypt. 110p.

Turekian, K.L., and Wedepohl, K.H., 1961. Distribution of elements in some major units of the earth crust.Geol. Soc. Am. Bull. 72, 641-664.

Vernon, R.H., 1984. Microgranitoid enclaves: globules of hybrid magma quenched in a plutonic environment. Nature (London), 304, 438-439.

Vernon, R.H.; Etherridge, M.A., and Wall, V.J., 1988. Shape and microstructure of microgranitoid enclaves: Idicators of magma mingling and flow. Lithos, 22,1-11.

Vorma , A., 1971. Alkali feldspar of the Wiborg rapakivi massif in Southeastern Finlande.Bull. Comm. Geol. Finlande, 246, 1-72.

Wahl, W., 1925. Die Gesteine des Viborger Rapaki- 
vigebietes. Fennia, 45, no.20.

Zaghloul, Z.M., and Khaffagy, M.B., 1965. Zircon in the granites of Aswan, Upper Egypt. U. A. R. Bull. Science and Technology, Assiut Univ., 8, 208-220.

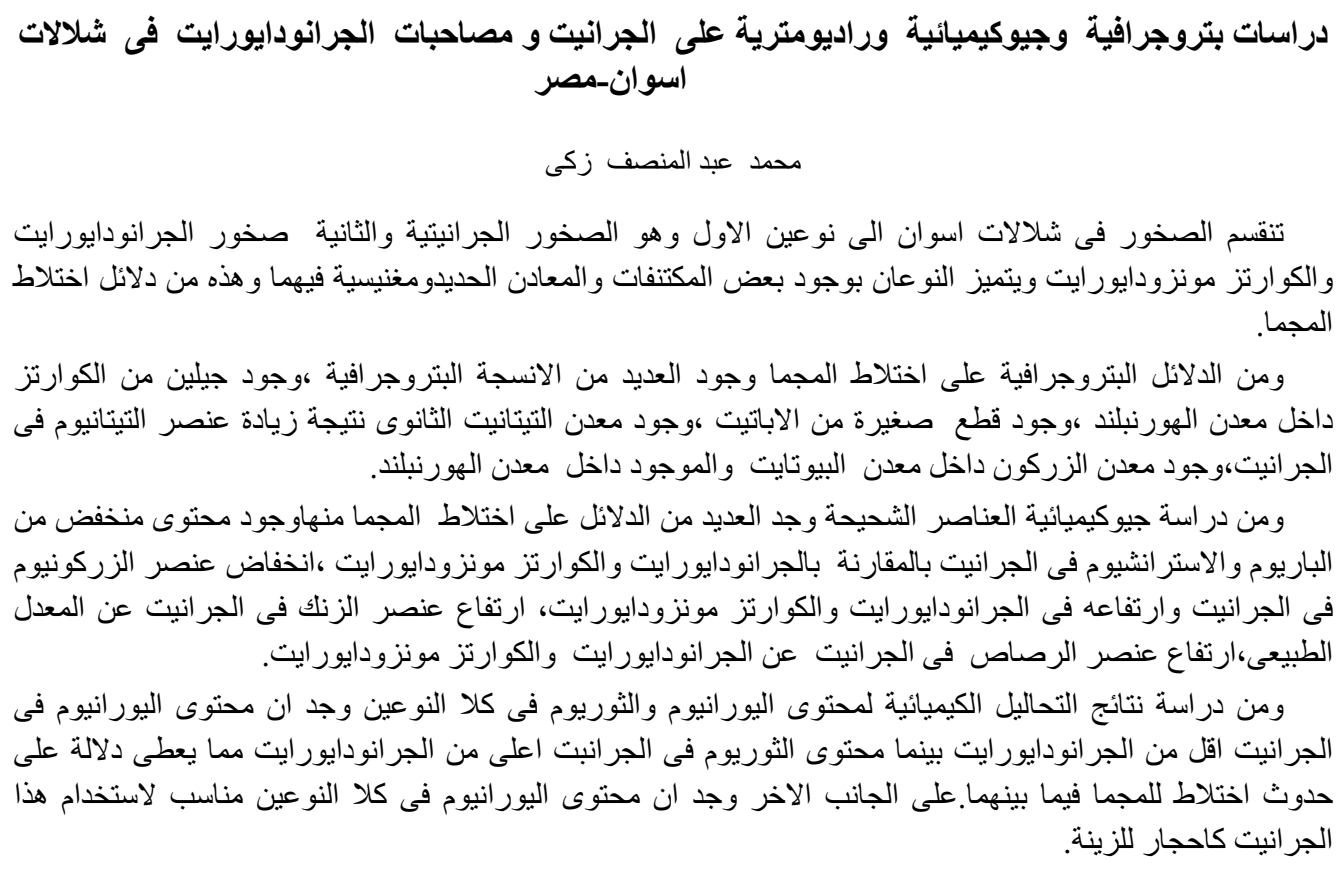

